\title{
The Interplay between Board Characteristics, Financial Performance, and Risk Management Disclosure in the Financial Services Sector: New Empirical Evidence from Europe
}

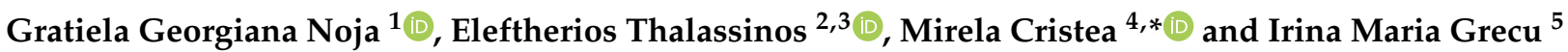 \\ 1 Department of Marketing and International Economic Relations, Faculty of Economics and Business \\ Administration, West University of Timisoara, 16 Pestalozzi Street, 300115 Timisoara, Romania; \\ gratiela.noja@e-uvt.ro \\ 2 Faculty of Maritime and Industrial Studies, University of Piraeus, 185-33 Piraeus, Greece; thalassinos@ersj.eu \\ 3 Faculty of Economics, Management and Accountancy, University of Malta, 2080 Msida, Malta \\ 4 Department of Finance, Banking and Economic Analysis, Faculty of Economics and Business Administration, \\ University of Craiova, Center for Banking and Financial Research, 13 A I Cuza Street, \\ 200585 Craiova, Romania \\ 5 Doctoral School of Economics and Business Administration, West University of Timisoara, \\ 16 Pestalozzi Street, 300115 Timisoara, Romania; irina.grecu96@e-uvt.ro \\ * Correspondence: mirelas.cristea@gmail.com
}

Citation: Noja, Gratiela Georgiana, Eleftherios Thalassinos, Mirela Cristea, and Irina Maria Grecu. 2021. The Interplay between Board Characteristics, Financial

Performance, and Risk Management Disclosure in the Financial Services Sector: New Empirical Evidence from Europe. Journal of Risk and Financial Management 14: 79. https://doi.org/ 10.3390/jrfm14020079

Academic Editor: Thanasis Stengos

Received: 30 January 2021

Accepted: 15 February 2021

Published: 17 February 2021

Publisher's Note: MDPI stays neutral with regard to jurisdictional claims in published maps and institutional affiliations.

Copyright: (c) 2021 by the authors. Licensee MDPI, Basel, Switzerland. This article is an open access article distributed under the terms and conditions of the Creative Commons Attribution (CC BY) license (https:/ / creativecommons.org/licenses/by/ $4.0 /)$.

\begin{abstract}
This paper empirically evidences the role played by board characteristics (skills, diversity, structure, independence) in supporting risk management disclosure and shaping the financial performance of European companies operating in the financial services sector. We exploit data selected from Thomson Reuters Eikon database in 2020 for the last fiscal year 2019 (FY0) on a longitudinal sample of 144 companies with the head offices in Europe ( 25 countries). Following an original empirical approach based on two modern financial econometric techniques, namely structural equation modelling (SEM) and network analysis through Gaussian graphical models (GGMs), the research endeavor outlines the decisive importance of an optimal board size, enhanced management skills, upward gender diversity (encompassed by women participation on board management), and structure (mainly a two-tier type, one management board, and a distinctive supervisory board) as fundamentals of risk management strategies, leading to improved financial achievements and a higher profitability for the analyzed companies.
\end{abstract}

Keywords: financial econometrics; risk management; board characteristics; financial performance; strategy; financial services

\section{Introduction}

The relationship between the board of directors' key features affecting governance, risk management disclosure, and financial variables/firm profitability represents a topical research subject largely approached in the literature. These credentials are also at the core of this research, being placed in the open conversation and ongoing debate on the importance of board characteristics-like board independence, size, background and skills, structure, and diversity - associated with the corporate governance (CG) and sustainable development activities, in shaping the financial performance of companies, particularly those operating in the financial services sector.

The rationale for examining the interplay between corporate governance variables, financial performance, and risk management resides from the essentials of risk management disclosure in the financial sector as a "leading paradigm, supporting organizations to identify, evaluate and manage risks at the enterprise level" (Anton and Nucu 2020, p. 1). It is a relevant topic of interest for companies, practitioners, and researchers in the field based on the increasing importance of corporate governance and board characteristics in 
providing sound paths for an enhanced financial performance and risk exposure mitigation (Florio and Leoni 2017), increased capital efficiency (Lechner and Gatzert 2018), and reduced uncertainty in stock return volatility, that becomes stronger over time (Eckles et al. 2014).

The relationship between board characteristics and risk management is grasped through the importance of adequate corporate governance mechanisms in limiting the excessive exposure of companies, particularly those in the financial services sector, to risk (Bunea and Dinu 2020). The further relationship between the board of directors' characteristics, risk management, and financial performance is also largely debated in the literature, being attested through the essential role played by the corporate governance board in supervising the activities of the company, as well as in the decision-making process, thus affecting the capability to successfully engage in reaching the objectives with spillover effects on firm profitability and overall performance.

Based on the underpinnings of the relevant literature, this paper aims to explore the relationship between board characteristics, risk management disclosure, and the financial performance of companies operating in the financial services sector in 25 European countries. Therefore, it is set to bring new evidence to attest that board characteristics, particularly board size, skills/capabilities, diversity, independence, are fundamental pillars for risk management and leveraged performance, being compulsory for accurate and effective management strategies, alongside with CG and sustainable development activities.

The paper entails significant contributions to the literature by offering a comprehensive perspective on the interlinkages and correlations between several important fundamentals of corporate governance, risk management, and financial performance (a three-fold approach) in the financial services sector, at the European level, based on an advanced empirical analysis. Therefore, it presents robust evidence on how board size, structure, diversity, background, and skills relate (positively or inversely) with the financial risk management in the presence of independent corporate governance board and compensation committees, along with their further cumulated impact on performance and firm profitability.

The structure of the paper covers brief theoretical reviews in the introduction section, followed by a detailed description of the data and methodology applied in Section 2, as well as main results encompassed by the research endeavor in Section 3. Lastly, the discussion and concluding remarks are presented in the final sections.

\section{Brief Literature Review}

The relationships between the board characteristics and firm profitability, within the corporate governance and sustainable development framework, have been largely debated in the literature. These explorations aimed to endorse risk management of the companies.

Risk management disclosure is, generally, assessed "via annual accounts and reports by corporate entities", in compliance with "rules and regulations governing financial reports", especially for financial institutions (Kakanda and Salim 2017, p. 839). These regulations are transposed into CG practices/code and analyzed in relation to the financial performance of the companies (Solomon et al. 2000; Kakanda and Salim 2017). Albeit, the risk management disclosure has no distinctive measurement, the main items to assess it revealed by the literature underpinnings (Abdullah et al. 2015; Kakanda and Salim 2017) are the availability of risk management committee, the existence of its responsibility and functions, targeted policies and objectives, and the subsistence of audit committee. The relationship between risk management disclosure and financial performance is, generally, appreciated as positive, as (Kakanda and Salim 2017) summarized when they investigated the literature review on this topic.

Financial performance is an essential coordinate generally accounted to capture the present state of a company. Firms always focus on reaching targeted financial performance, as this describes their efficiency in coordinating resources, along with the capability to profit or their profitability, and the ability to survive on the market at odds with the 
existing competitors. Financial performance explains how solid companies are financially sound, especially in terms of cash flow. The investors, creditors, and suppliers will analyze the company's financial performance before deciding to make any transaction with the company before any form of collaboration. Positive financial performance results will strengthen the confidence of creditors and investors in the activity and operation of a company. There are many factors that may affect the financial performance of a company. Such factors can be external, such as economic development, economic growth, or political stability (Hosny 2017), or internal, such as firm liquidity (Muturi and Omondi 2013), efficiency, effectiveness, and competence of a firm management (Skandalis et al. 2008). The uncertainty and inconsistency of such factors cause fluctuations on the financial performance of companies every year.

Year after year, many variables are used in the literature and by practitioners to measure the financial performance of a company, ranging from long run to short term measures, as well as non-market-oriented credentials (Pirtea et al. 2014; Ozen et al. 2015; Băndoi et al. 2021). Some of these measures refer to an upturn in return on assets (ROA), increased cash flow, earnings per share (EPS), assets, raised dividends (DPS), and higher sales (Coles et al. 2001; Abdullah 2004; Sichigea et al. 2020). Return on assets (ROA) is a common measure of a company's financial performance related to its total assets, giving a view of how effective management is exploiting its assets to generate earnings. Return on equity (ROE) is another proxy for the financial performance of companies, measuring the profitability in relation to stockholders' equity. Both indicators of relative financial profitability, ROA, and ROE, are largely considered by various studies when related with management features (e.g., Dehaene et al. 2001; Noja et al. 2020), but also the absolute measurement of financial profitability, namely earnings before interest and taxes (EBIT) (Noja et al. 2020; Suciu et al. 2020).

By acknowledging the main findings of previous studies, five dependent variables were used in this study to capture the financial performance, namely return on assets (ROA) and return on equity (ROE), as traditional financial performance proxies, along with earnings before interest and taxes (EBIT), earnings per share (EPS), and dividend per share (DPS).

The board of directors' concept comes from the motivation and stimulus that play a significant role in coordinating the activity of the board of directors and may be captured as a link between the company management and company's shareholders (Kiel and Nicholson 2003; Bonn 2004; Murphy and McIntyre 2007). It is in charge with the decision-making process within the company and responsible for protecting and maximizing shareholder wealth and claims, over-watching the performance of the company, and evaluating the efficiency of the managers. The diversity of the board of directors in a company embeds representation in various fields/dimensions of that company, thus being associated in a positive way with financial performance.

The main purpose of the board of directors is known as the monitoring and the ratification of management's decisions and the supervision of the actions of managers and/or directors. In this perspective, the board should ensure that the company's actions are based on the firm's strategy, which are aimed at increasing the value for all their stakeholders, by preventing at the same time the negative management behavior and practices that can lead to failures or disagreements. The board characteristics are related to board size, diversity, its independence, background, and skills and structure, associated with the corporate governance and sustainable development activities (Kakanda and Salim 2017).

The board size shows the total number of directors who can impact the corporate governance policies of business and the company's financial performance (Yermack 1996; Pucheta-Martínez and Gallego-Álvarez 2020). The board size is an essential variable of the board characteristics that can be considered as a proxy to measure the board efficiency (Jia and Zhang 2013). Larger councils may be more inefficient, since the agreements between the parties are more difficult to reach due to the existing different interests. 
Gender diversity is known as one of the most controversial and argued topic of the board's composition, especially on environmental and social issues, existing many theories that try to explain the role of women as members of the board, taking into consideration a variety of perceptions and perspectives. A woman as a board member is recognized to be more involved, dedicated, motivated and diligent, less self-centered when it comes to decision-making, which assure a greater efficiency of the board (Coffey and Wang 1998; Huse and Solberg 2006). A woman director will bring quite different and open-minded sociological perceptions and understandings to broaden the scope of decision-making at the board level (Swartz and Firer 2005). Board diversity by gender brings numerous effects on financial performance, predominantly positive effects, as attested by practical and empirical evidence. If a negative relation appears in the econometric modelling, it means that the presence of a woman as a member of the board reduces the company's financial performance. When different countries are analyzed, different results appear in the case of female directors. It is known that the companies in the United States or Sweden, for example, report that the proportion on females on boards of directors generates a positive influence on the financial performance of those companies.

However, such results are not universally accepted, taking into consideration other studies in Sweden (Du Rietz and Henrekson 2000) and Norway (Randöy et al. 2006), where it is entailed that female directors do not have any implications on the financial performance of firms and the results obtained by researchers so far are not so conclusive. The literature also evidences favorable linkages between the gender diversity of the board and audit committee members in terms of financial performance, which implies that a commercial bank, for example, with a significant gender mix of the audit committee, have improved the financial performance. A positive relationship grasps that companies with higher audit attributes show a big probability of having high financial performance, as well.

In another approach, (Berrone and Gomez-Mejia 2009) found a favorable connection between $\mathrm{CEO}$ remuneration and the strategies oriented to pollution prevention, among companies in the United States that operate in the polluting sector, although CEO remuneration is usually not associated with the control of pollution "at the end of the pipeline".

The board structure type induces, also, different impacts on the efficiency of the board. According to the agency's theory, the independent boards successfully fulfill the role of monitoring effectively by asking questioning and management evaluating in an objective way, which reduces the agency's costs and improves the efficiency of a company (Millet-Reyes and Zhao 2010; De Villiers et al. 2011). Since independent directors have intangible financial interests in the company, they seem to be less influenced or may be reliant on executive management (Coffey and Wang 1998; Liao et al. 2015; Haque 2017). Consequently, it is more presumptive to show an opportunistic behavior of managers. By the side of a single board (known as "unitary" or "one-tier"), the board structure may be organized on two distinctive boards, one for management activities and another for supervisory ones (known as "two-tier" board), with implications on the financial performance only when the companies are under financial distress (Rose 2005; Millet-Reyes and Zhao 2010).

An effective risk management is achieved through an independent, highly-skilled, experienced, and dedicated governance board, further leading to an increase in the portfolios of assets as a generator of return and reduced operational costs. Additionally, (Bunea and Dinu 2020, pp. 1250-1251) highlight "a positive and significant link between the boards of directors dimensions and the solvability of the analyzed banks", as well as "a direct link of medium intensity between the level of the total own funds and the boards of directors characteristics, referring to the gender diversity, the members education and the dimension of the boards of director".

The findings confirm that some studies realized so far, such as (Al-Matari et al. 2012), had the purpose of assessing the existing relationship between the board of directors' characteristics and the financial performance of non-listed companies (in the case of Kuwaiti companies) that found a positive sense for the duality of CEOs and for improving the financial performance. Moreover, (Ujunwa 2012) showed that the duality of the board is related 
in a positive way to the financial performance of companies. Additionally, (Abu et al. 2016) found that a foreign director may be correlated or positively and significantly influenced financial performance. Such mixed results on the relationship between the characteristics of the board and financial performance of a company have revealed a lot of possible areas for future research. In this case, a lot of companies have to the face the challenge of maximizing shareholder value, while trying to take into consideration the interests of their other stakeholders.

The characteristics of the board and the interdependency with the financial performance should be encouraged and supported. After a critical assessment of the literature, it can be noted that researchers, mainly, show that board characteristics have a positive and significant effect on the financial performance of a company or even a bank.

\section{Materials and Methods}

\subsection{Data}

We exploit data selected from the Thomson Reuters Eikon database in 2020 for the last fiscal year 2019 (FY0) on a longitudinal sample of 144 active public companies with the head offices in Europe (25 countries, namely, Austria- 5 companies; Belgium-2, the Czech Republic, Denmark—4, Finland-2, France-6, Germany-8, Greece-5, Guernsey8, Hungary-1, Ireland - 5, Italy-17, Jersey-2, Liechtenstein-1, Luxembourg-1, the Netherlands-4, Norway-9, Poland-11, Portugal-1, Romania-2, Russia-4, Spain-10, Sweden-5, Switzerland-12, the United Kingdom-19) operating in the banking and financial services sector, namely: Banks, Investment Banking and Brokerage Services, Multiline Insurance and Brokers, Reinsurance, Closed End Funds, and Mutual Funds. The sample selection across Europe was performed based on the country of headquarters in Europe as the main criteria and country of incorporation as an additional subsequent criterion. The data are included both for FY0 and the next fiscal year (FY1) and it is considered for 2019 also by accounting the limitations of the sample extracted from the Thomson Reuters Eikon database.

The compiled dataset was processed in Stata 16 and encompasses the following indicators:

- Corporate governance and board characteristics (FY0): “Corporate Governance Board Committee" (CGBC), binary data, 0-No, 1-Yes; "Board Attendance" $(B A)$, binary data, 0-No, 1-Yes; "Number of Board Meetings" (BM), number (median); "Board Structure Type" (BST), multi-category variable, 1-unitary (a single board), 2-twotier (two boards, one management board and another supervisory board), 3-mixed; "Board Size" (BS), number (median); "Board Background and Skills" (BBS), binary data, 0-No, 1-Yes; "Board Gender Diversity" (BGD), \% (median); "Management Departures" (MD), binary data, 0-No, 1-Yes; “Women Managers" (WM), \% (median); "Bribery, Corruption and Fraud Controversies" (BCFC), binary data, 0-No, 1-Yes; "Compensation Committee Independence" (CCI), \% (median);

- Financial performance and firm profitability indicators (FY1): "Return on Assets" $(R O A), \%$; "Return on Equity" (ROE), \%; "Earnings before interest and taxes" (EBIT) (mean, USD); “Earnings per share" (EPS), (mean, USD); “Dividend per share" (DPS) (mean, USD);

- Sustainable development indicators (FY0): “Environmental, Social and Governance (ESG) reporting scope" (ESG_RS), \% (median); “Corporate Social Responsibility (CSR), sustainability committee" (CSR_SC), binary data, $0-N o, 1-Y e s ;$

- " $\quad$ "ASSETS" (FY1): As a control measure for the size of the company, capturing the total value of the assets (USD).

Summary statistics of the indicators/variables comprised by our econometric models are presented in Table 1. 
Table 1. Summary statistics of fundamental variables used in econometric modelling, 2019.

\begin{tabular}{cccccc}
\hline Variables & N & Mean & $\begin{array}{c}\text { Standard } \\
\text { Deviation }\end{array}$ & Minimum & Maximum \\
\hline BCFC & 144 & 0.3541667 & 0.4799293 & 0 & 1 \\
CGBC & 144 & 0.2777778 & 0.4494666 & 0 & 1 \\
CCI & 129 & 72.94589 & 29.00742 & 0 & 100 \\
BA & 144 & 0.4236111 & 0.495855 & 0 & 1 \\
BM & 122 & 11.89344 & 6.71597 & 3 & 43 \\
BST & 144 & 1.583333 & 0.6637465 & 1 & 3 \\
BS & 144 & 11.10417 & 4.235578 & 3 & 1 \\
BBS & 144 & 0.8541667 & 0.354171 & 0 & 57.14 \\
BGD & 144 & 29.28736 & 13.08738 & 0 & 1 \\
MD & 144 & 0.0902778 & 0.2875796 & 0 & 72.07 \\
WM & 97 & 35.35351 & 12.94517 & 5.56 & 1 \\
CSR_SC & 144 & 0.5555556 & 0.4986384 & 0 & 700 \\
ESG_RS & 113 & 91.06681 & 18.537 & 2.22 & 6.3 \\
ROA & 144 & 0.8188958 & 0.9709631 & -0.7 & 29.458 \\
ROE & 144 & 9.013201 & 7.831185 & -17.3 & 41.9 \\
EBIT & 124 & $2,600,000,000$ & $4,560,000,000$ & $-10,100,000$ & 36.69 \\
EPS & 129 & 3.04031 & 5.95377 & -0.09 & 0 \\
DPS & 132 & 1.62303 & 4.178183 & 0 & $2,760,000,000,000$ \\
ASSETS & 126 & $262,000,000,000$ & $482,000,000,000$ & $441,000,000$ & \\
\hline N total & 144 & & & & \\
\hline
\end{tabular}

Source: Own process of data retrieved from the Refinitiv (2020) database.

We note that there are important variations across the sample (Table 1), particularly in regards to the financial performance and firm profitability indicators, whose values range from -0.09 to 41.9 in the case of EPS or even from -17.3 to 62.358 in the case of $R O E$. The mean indicator displays values close to the maximum limit (1 or 100) only for the "Compensation Committee Independence" (CCIND), "Board Background and Skills" (BBS), and "ESG reporting scope" (ESG_RS), while for the "Bribery, Corruption and Fraud Controversies" (BCFC), "Corporate Governance Board Committee" (CGBC), "Board Structure Type" (BST), "Management Departures" (MD), and "Dividend per share" (DPS) indicators, the mean is near the minimum limits. These results show different situations across policies of companies from the banking and financial services sector, on corporate governance, board characteristics, and sustainable development with implications on financial performance and risk management.

\subsection{Methodology}

The main methodological credentials encompass structural equation modelling (SEM) and network analysis through Gaussian graphical models (GGMs). Both approaches have the origin in path analysis and imply a variance-covariance matrix, aiming to identify how variables (including latent unobserved variables) are related to each other, being widely used for modelling longitudinal data.

Structural equation modelling (SEM) encompasses a set of modern multivariate econometric techniques extremely popular in quantitative social sciences due to its sophistication in estimating latent or unobserved variables through other observed variables and accurate assessment of measurement errors.

Our general SEM model is a measurement model developed based on the theoretical credentials outlined in the previous section. It is further tested against the dataset for the estimation of financial risk management and mitigation (FRM) as a latent (factor) variable resulting from specific observed variables, namely board characteristics and management features (corporate governance and sustainable development policies). FRM is captured based on the relevant theoretical groundings as being framed by specific corporate governance features (Kakanda and Salim 2017), independent of CC and CGB, and particularly board characteristics (engagement through BA and BM, size, BS, and structure- 
BST, background and skills_-BBS, and gender diversity_-BGD and WM), largely depending on the firm size, as well (captured through the total value of the assets, as a control variable). Being an unobserved factor (latent) variable, FRM is not directly measured and therefore presents the advantage of not having a measurement error associated with it. Therefore, FRM allows estimating the relationships configured in our research in a predefined framework among the previously entailed variables without a measurement error, thus overpassing the issue of unreliability of measures.

All these credentials further impact the financial performance and firm profitability of the considered European companies operating in the financial services sector. The general setting of the SEM model is described in Figure 1.

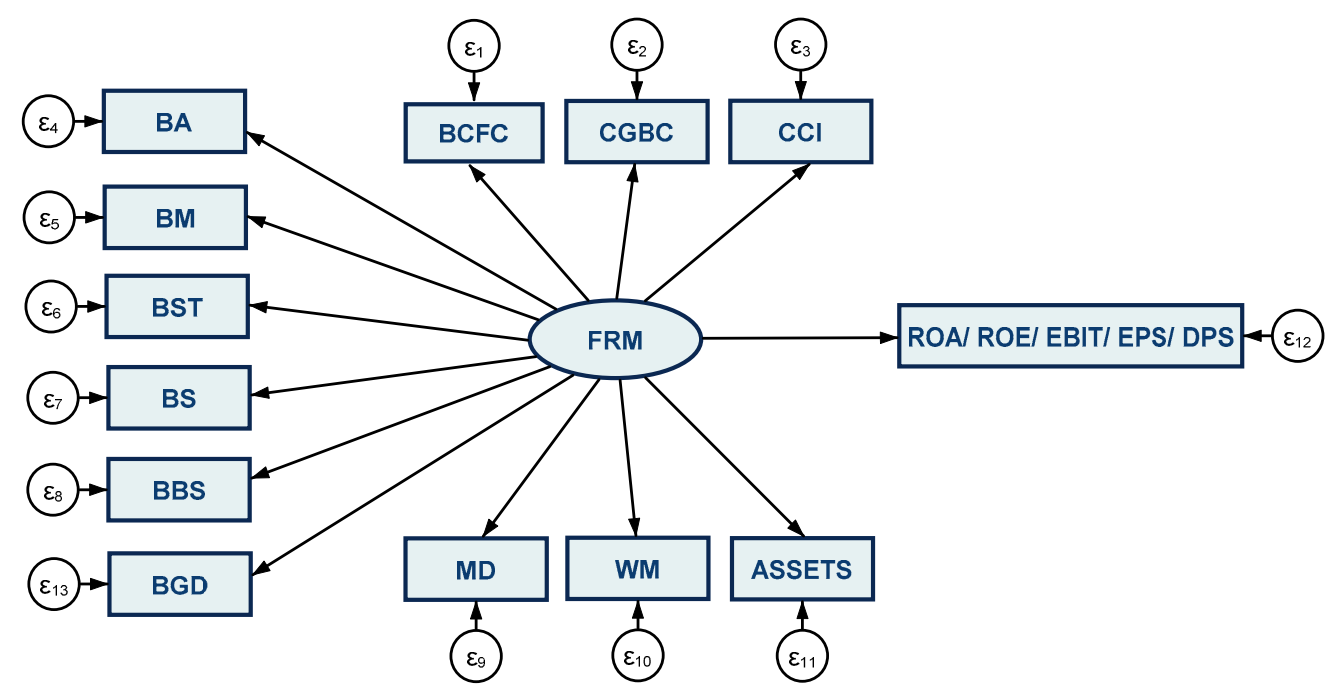

Figure 1. General research model configured to assess the interplay between board characteristics, risk management, and financial performance. Source: Authors' research and design in Stata 16. Note: BA: Board attendance; BM: Board meetings; BST: Board structure type; BS: Board skills; BBS: Board background and skills; BGD: Board gender diversity; BCFC: Bribery, corruption and fraud controversies; CGBC: Corporate governance board committee; CCI: Compensation committee independence; MD: Management departures; WM: Women managers; ASSETS: Total values of the assets (USD); FRM: Financial risk management and mitigation; ROA: Return on assets; ROE: Return on equity; EBIT: Earnings before interest and taxes; EPS: Earnings per share; DPS: Dividend per share.

Going beyond the classical linear regression analyses, SEM examines the causal relationships among variables, while controlling simultaneously for the estimation error as the greatest advantage in empirical research. SEM allowed us to set out the degree of correlation (path coefficients) that captures the significance of a certain path of impact from cause to effect (Beran and Violato 2010).

According to (Nunkoo and Ramkissoon 2012, p. 777), the advantages of SEM over the regression analysis relate to: "Modelling of measurement errors and unexplained variances, simultaneous testing of relationships, ability to link micro- and macro-perspectives, and best-fitting model and theory development". Another benefit of SEM results from the fact that the multitude of variables and connections captured by our model are naturally handled with SEM, while in a classical regression model, multiple indicators cause collinearity problems and small increments in variance accounted for (Brannick 1995, 2020).

Gaussian graphical models (GGMs) are developed as a network model of conditional associations configured based on partial correlations which are graphically represented through the width, saturation, and color (red for negative correlations and blue for positive correlations) of the edges between nodes.

GGMs entail an undirected network of partial correlation coefficients (both positive and negative). It is graphically reflected through the absolute strengths (width and satura- 
tion of the edges between nodes), thus being a network model of conditional associations and avoiding spurious correlation.

The partial correlation (pcor) determined in the GGMs can be calculated as in Equation (1) (Gujarati 2003):

$$
r_{x y \cdot z}=\frac{r_{x y}-r_{x z} r_{y z}}{\sqrt{1-r_{x z}^{2} \sqrt{1-r_{y z}^{2}}}}
$$

where $r$ represents the correlation degree.

GGMs are essential in our research also due to the ability to handle different types of variables, since we have 13 measures of board characteristics and management policies (CG and CSR), one control measure, and five different financial performance and profitability measures, all with different measurement units (binary, absolute values, multi-category etc.) that need to be accounted in a sequential approach, as a complex network, in order to be able to model conditional associations, namely to capture the degree in which the variables are independent after conditioning on all other variables in the dataset.

GGMs have provided their utility as an exploratory data analysis tool and bring several additional important benefits to classical regression models, that entail "which variables predict one-another, allow for sparse modeling of covariance structures, and may highlight potential causal relationships between observed variables" (Epskamp et al. 2018, p. 453).

The research hypotheses $(\mathrm{H})$ are:

Hypotheses 1 (H1). Board characteristics of the companies operating in the financial services sectors and their financial risk management/performance are positively interplayed.

Hypotheses 2 (H2). Corporate governance/sustainable development activities of the companies operating in the financial services sectors and their financial risk management/performance are positively associated.

\section{Results}

\subsection{Results of Structural Equation Modelling (SEM)}

To acknowledge the results obtained through SEMs, we have firstly checked their robustness by applying specific tests for each of the five models, in terms of confidence (Cronbach's Alpha, Appendix A, Table A2), the Wald test for equations (Appendix A, Table A3), and the Goodness-of-fit tests (Appendix A, Table A4). Cronbach's Alpha attests the confidence of the five models (total scale is over 0.6 for each model). Goodness-of-fit tests reveal a good fit for our models. The coefficient of determination (CD) is around $90 \%$ for all the models, which points out the share in which all the considered variables influenced each dimension of the financial performance.

The results of the financial risk management (FRM), as a latent variable, built for each financial performance and firm profitability indicator (Figure 2, Appendix A, Table A1), highlight that the board characteristics of the European financial services institutions are statistically significant and positively influenced only for the following credentials: "Board Size" $(B S)$ and "Management Departures" $(M D)$, in the case of all the considered SEM models $(p<0.001)$, and "Number of Board Meetings" $(B M)$, in the case of the interlinkages with $R O A(p<0.05)$.

The existence of the corporate governance committee (CGBC) and the firm size ("ASSETS") are positively associated with FRM, for all the associations with financial performance and firm profitability indicators (Figure 2a-e, Appendix A, Table A1), which are incredibly significant from the statistical point of view $(p<0.001)$. On the one hand, these results suggest that the bigger the financial services institution is, the better FRM is managed. On the other hand, corporate governance strategies endorse the risk management disclosure. 


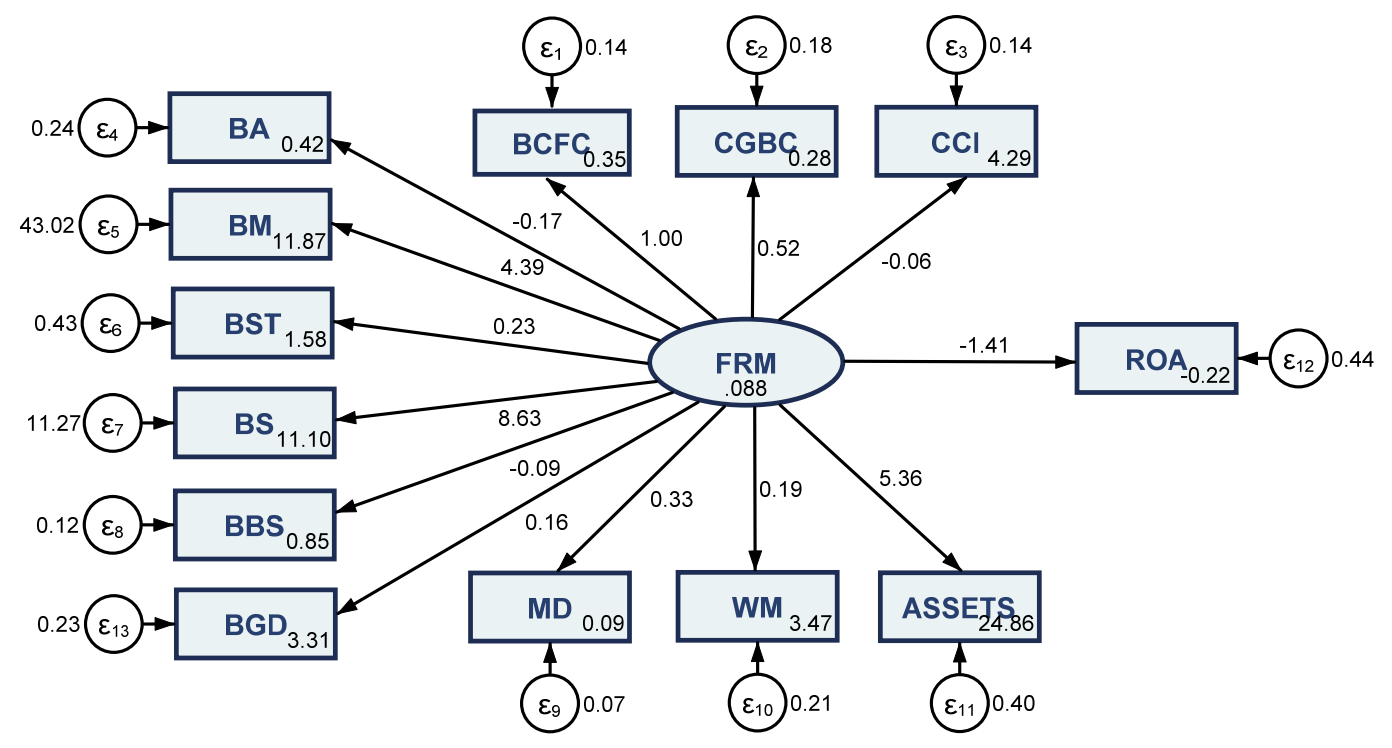

(a)

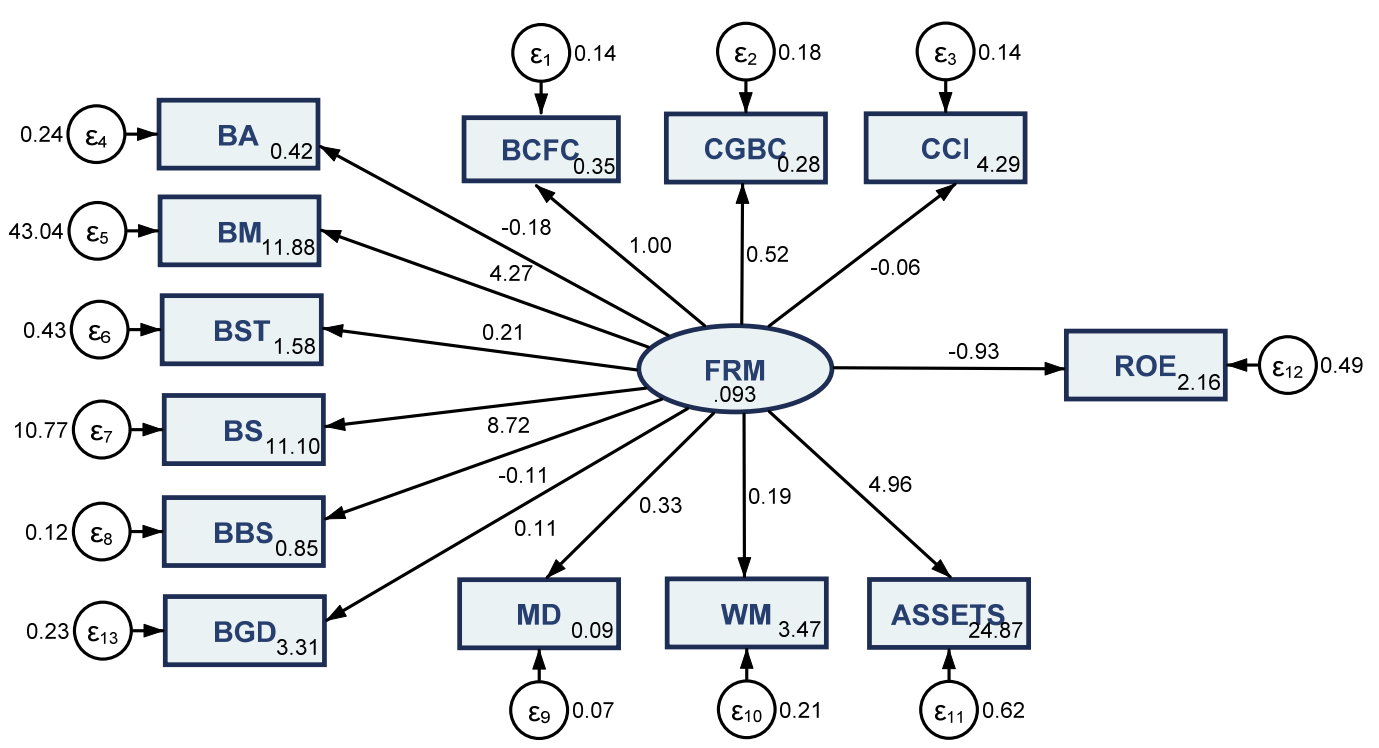

(b)

Figure 2. Cont. 


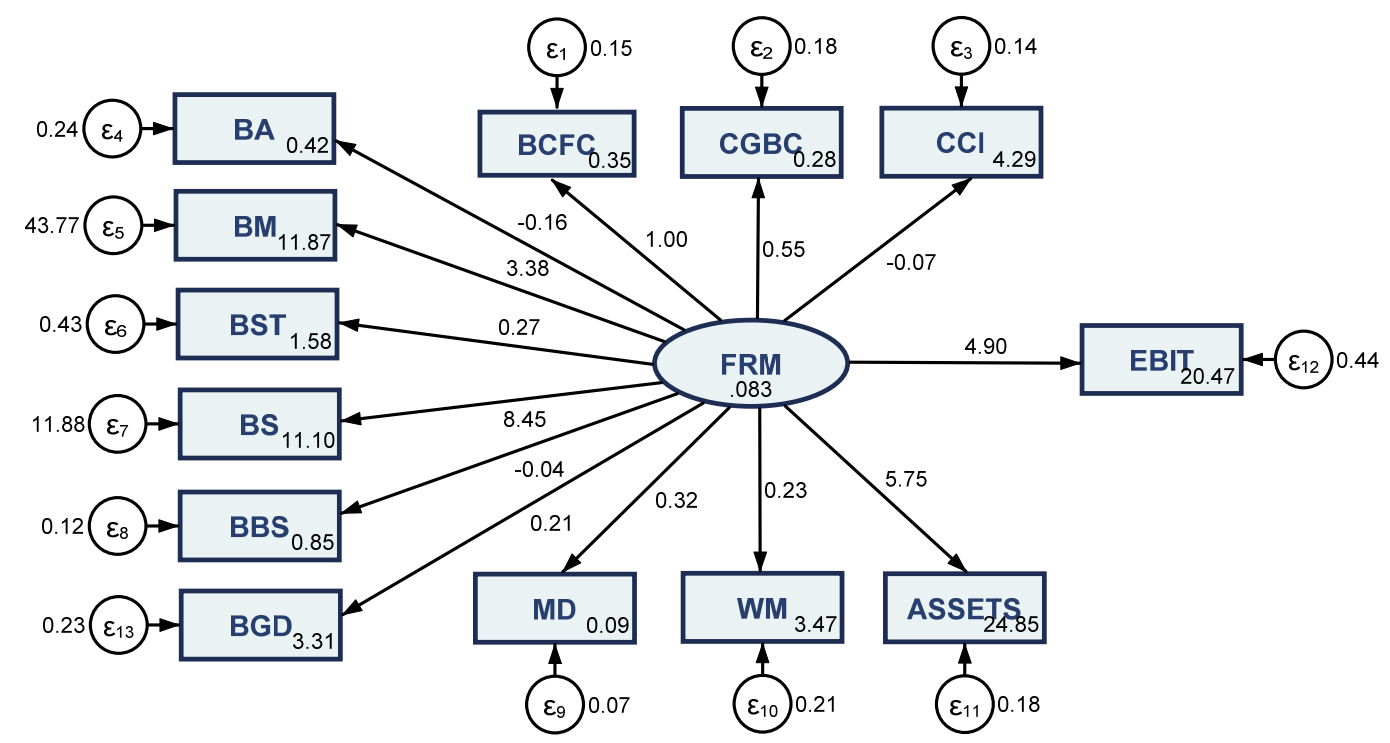

(c)

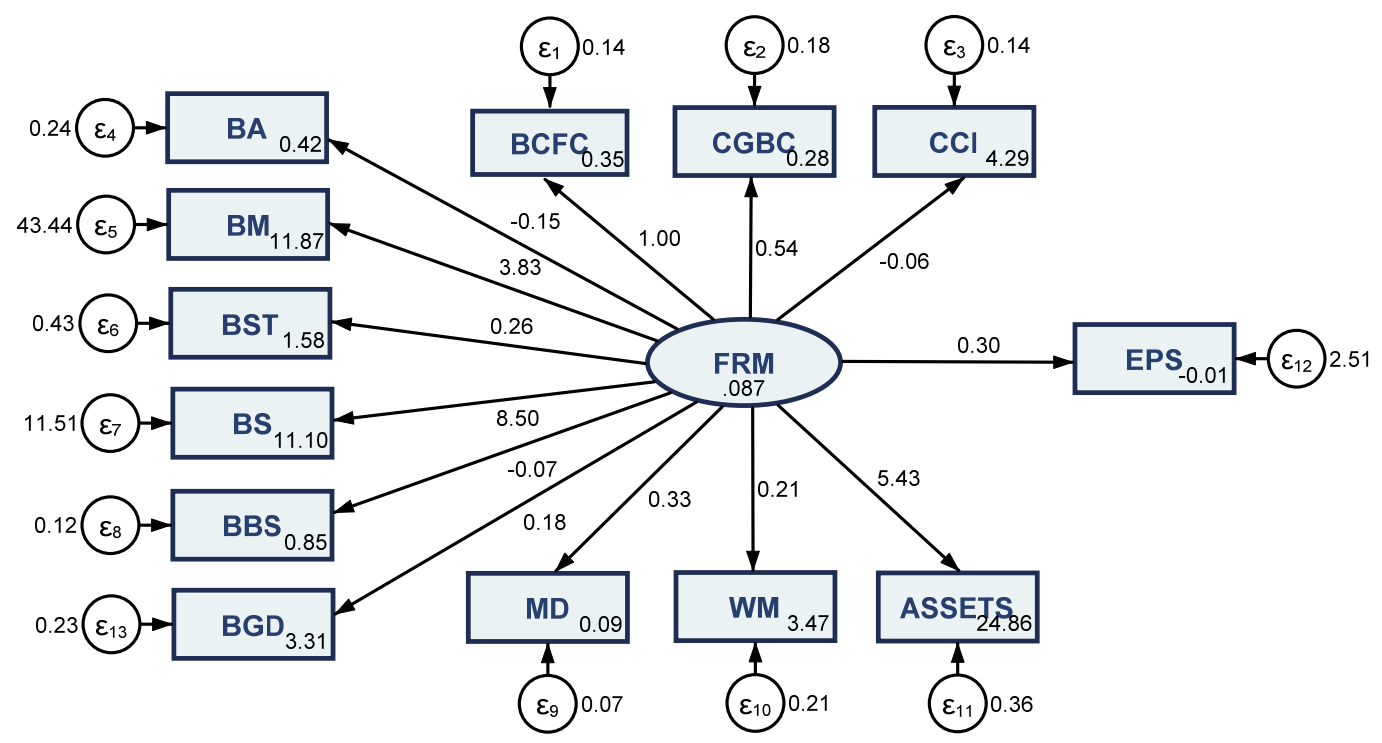

(d)

Figure 2. Cont. 


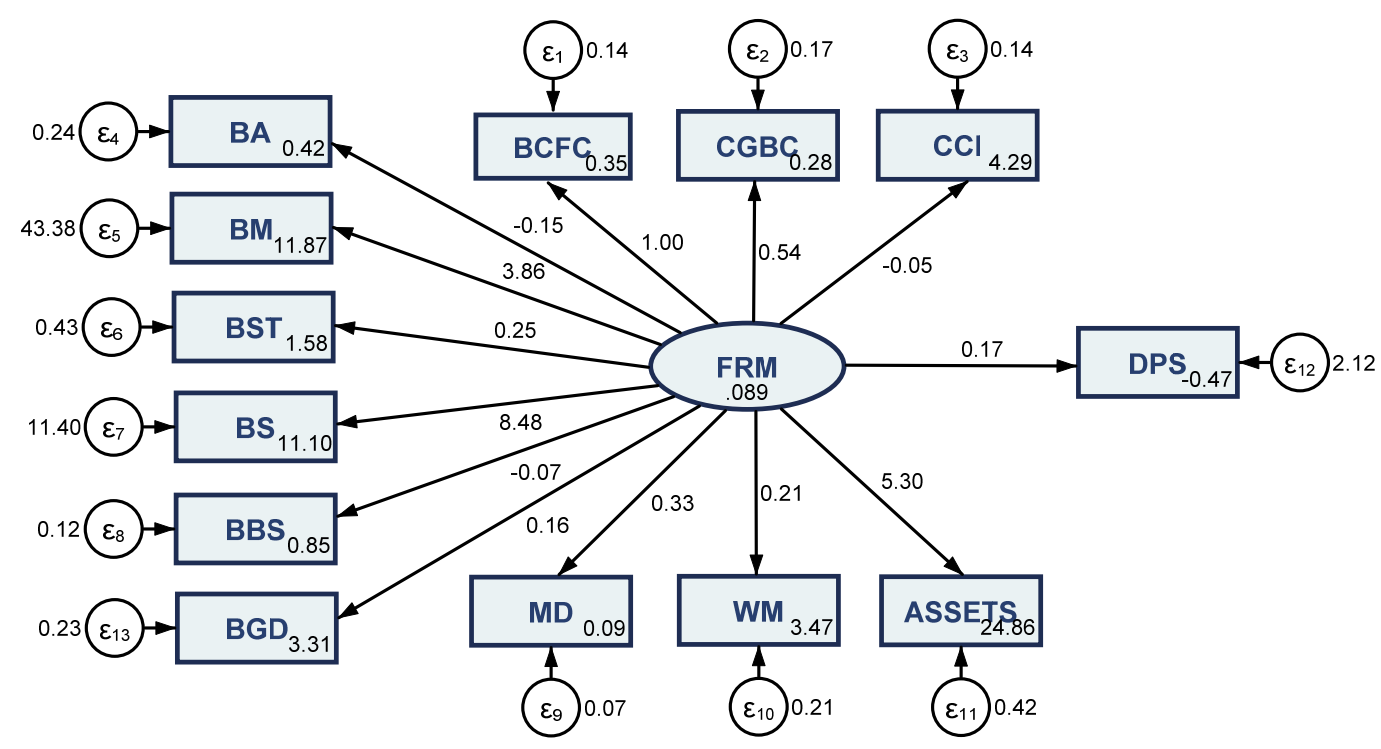

(e)

Figure 2. SEM results in various financial performance and profitability scenarios/measurements: (a) Linkages with return on assets (ROA); (b) linkages with return on equity (ROE); (c) linkages with earnings before interest and taxes (EBIT); (d) linkages with earnings per share (EPS); (e) linkages with dividend per share (DPS). Source: Authors' research in Stata 16.

In regards to risk management in connection with financial performance and firm profitability dimensions, considering the interlinkages with board characteristics and management features (corporate governance and sustainable development policies), there are unfavorable implications both for $R O A$ and $R O E(p<0.001)$, more pronounced for $R O A$ (the coefficient is -1.414 for $R O A$, compared with -0.931 for $R O E$ ). Positive influences were induced only for EBIT ( $p<0.001)$, while for the earnings and dividend per share (EPS and DPS), the influences are not statistically significant.

These results require adequate strategies and accurate measures that need to be implemented by the financial services institutions to improve their financial performance in a relative form (ROA and $\mathrm{ROE})$.

\subsection{Results of Gaussian Graphical Models (GGMs)}

The results of the GGMs, built through the partial correlation method (pcor) (Figure 3), further account each sequential approach between all the considered variables, after conditioning on all other indicators included in the dataset.

The linkages between all the considered variables (Figure $3 a, b)$ capture the following associations in terms of financial performance and firm profitability dimensions:

- $\quad$ Positive synergies with ROA related to the size of the board (BS), departures of management (MD), the skills of board and its background (BBS), the type of structure of board (BST) (a single board, two-tier-one management board and another supervisory board, or mixed structure), and the existence of a (CG) board and committee (CGBC), on the one hand, and negative ones in regards to the connections with the independence of compensation committee (CCI) and CSR sustainability committee (CSR_SC);

- Favorable linkages with ROE in regards to the CSR sustainability committee (CSR_SC), women's involvement in board management (WM), the ESG policies (ESG_RS), and the independence of compensation committee (CCI), and unfavorable ones with the size of the board (BS) and departures of management (MD);

- Positive influence on EBIT in relations to "Bribery, Corruption and Fraud Controversies" (BCFC) and the size of the board (BS), and negative ones in regards to the 
type structure of board (BST) (a single board, two-tier-one management board and another supervisory board, or mixed), and the diversity of board by gender (BGD);

- $\quad$ Earnings per share (EPS) is positively associated with women's involvement in board management (WM), the independence of compensation committee (CCI) and sustainable development indicators, namely CSR committee (CSR_SC) and ESG reporting actions (ESG_RS), on the one hand, and negatively related with size (BS) and skills of board and its background (BBS), board meetings (BM), and attendance (BA), and the existence of (CG) board (CGBC), on the other hand;

- Dividend per share (DPS) is favorably linked with size (BS) and board attendance (BA), but also with skills of board and its background (BBS) and the existence of (CG) board (CGBC), and unfavorably connected with women's involvement in board management (WM), sustainable development indicators, namely CSR committee (CSR_SC) and ESG reporting actions (ESG_RS), and the independence of compensation committee (CCI).

Therefore, specific policies and strategies in terms of board characteristics, sustainable development, and corporate government dimensions are necessary, in order to improve the financial performance and firm profitability of companies from the financial services sectors and to disclose the financial risk management.

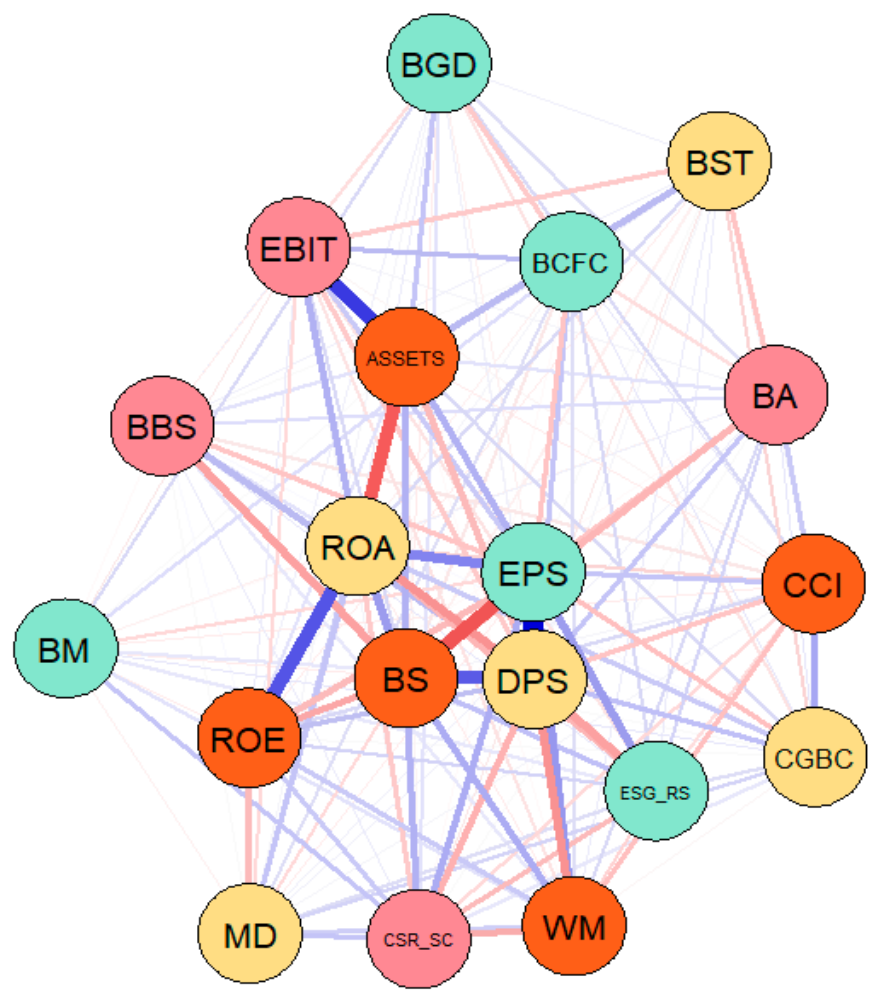

(a)

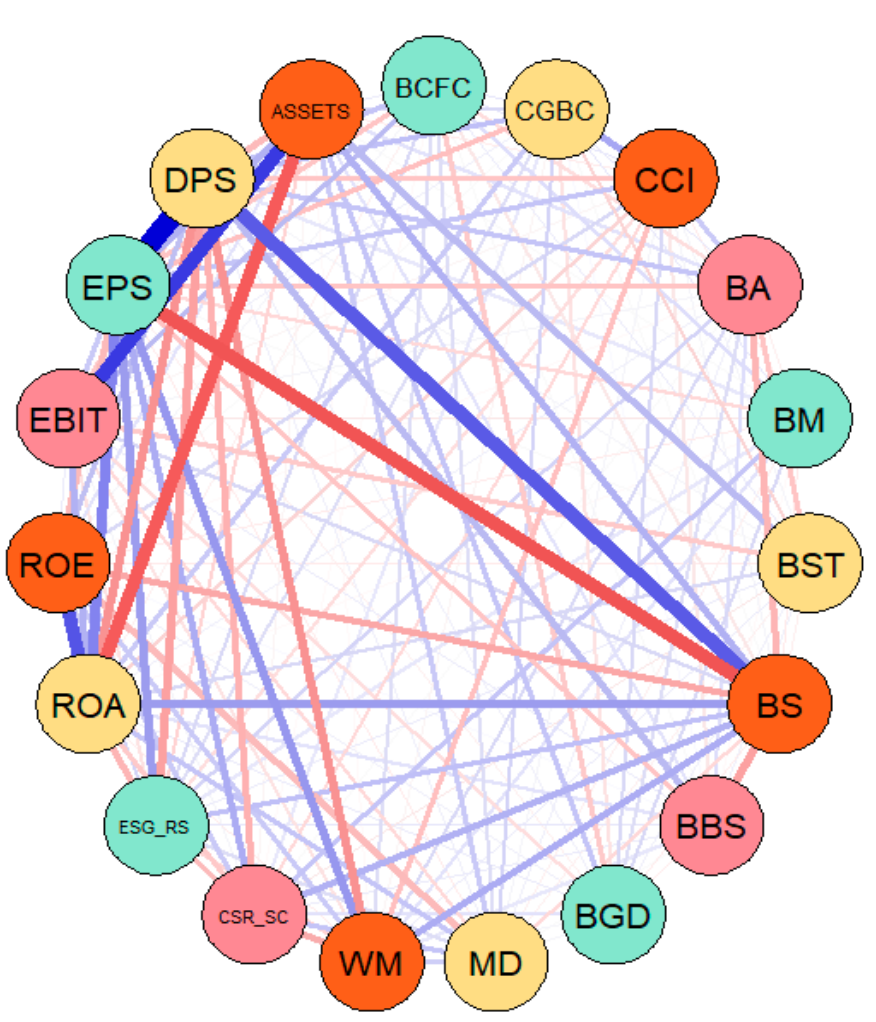

(b)

Figure 3. Gaussian graphical models (GGM) results-networks processed through the partial correlation (pcor) method: (a) Spring structure; (b) circle structure. Source: Authors' own research in RStudio 3.6.3.

\section{Discussion}

Based on the SEM models, where all the variables are logically connected in a structured framework, and the GGMs results for each sequential association between the variables, our 1st hypothesis, H1: "Board characteristics of the companies operating in the financial services sectors and their financial risk management/performance are positively interplayed", is partially fulfilled. 
Thus, only for a few features of the board, namely: The size (a mean of over 11 board members, according to Table 1), no departures from the board (the mean is 0.0902778 , near the minimum limit of 0 departures, as presented in Table 1), and the meetings held (a mean of 11 meetings across one year, Table 1) interrelated with each financial performance dimension, the financial risk could be disclosed (SEM results).

For each conjunction between board characteristics and financial performance (GGMs results), there are different implications in terms of variables associations. Thereby, the size of the board positively influences profitability related to assets (ROA), operating earnings (EBIT), and dividends received by shareholders (DPS). These results are similar to those obtained by (Pucheta-Martínez and Gallego-Álvarez 2020), considering the board size and firm performance measured by Tobin's $Q$ of various companies from all the world's geographic areas. The existence of high board skills and its background positively interrelate with firm performance related to assets (ROA) and with dividends adequate to shareholders (DPS). The type of structure of the board, most of the European financial institutions being characterized by a two-tier type, namely one management board and a distinctive supervisory board (mean is 1.583333 , as shown in Table 1) favorably interplays with financial performance related to assets (ROA). Similar findings were revealed by (Millet-Reyes and Zhao 2010; Al-Matari et al. 2012; Rose 2005) (but only when the companies are under financial distress). An average share of over 35\% women participation on board management (the mean is 35.35351, according to Table 1) and the independence of compensation committee (the mean is almost $73 \%$, as shown in the results in Table 1) induce positive implications on financial performances related to equity, namely ROE and earnings/profits obtained per share (EPS), being similar also with findings obtained by (Pucheta-Martínez and Gallego-Álvarez 2020), but also (Coffey and Wang 1998), and opposite to Du (Randöy et al. 2006), in the case of female participation in the companies' board from Sweden, respectively Norway. Low "bribery, corruption and fraud controversies" (the mean is near the minimum limit, namely .3541667, according to the statistics results in Table 1) positively influence operating earnings (EBIT).

According to both sets of results of SEM and GGMs, the 2nd hypothesis, H2: "Corporate governance/sustainable development activities of the companies operating in the financial services sectors and their financial risk management/performance are positively associated", is fulfilled. The CG activities deeply uphold risk management disclosure, when all the variables are interlinked (SEM findings). When CG is related to each financial performance dimension (GGMs results), its positive implication is associated only with the financial institution's performance related to assets (ROA) and with dividends adequate to shareholders. In regards to sustainable development implications, the percentage of over $91 \%$ of the ESG reporting scope for the European financial institutions (mean is 91.06681, Table 1) and the medium existence of CSR sustainability committee (mean is .5555556, Table 1) suggest that these actions induced favorable implications on the financial performance expressed by the return on equity (ROE) and earnings/profits obtained per share (EPS). These results are opposite to those obtained by (Suciu et al. 2020), which found positive implications of the ESG reporting scope only on operating earnings (EBIT), when they analyzed them jointly with social inclusion and human capital dimensions for all the companies with head offices in Europe. Different results were obtained also by (Cho et al. 2019) in the case of CSR implications upon companies' performances listed on the Korea Exchange, which found favorable implications only in the case of a social component of CSR on the return on assets.

\section{Conclusions}

The main contributions of our research are assessing and acknowledging the paramount significance of the interplay between board characteristics, risk management disclosure, and financial performance of companies with headquarters in Europe, operating in the financial services sector. 
Following an original empirical approach based on two modern financial econometric techniques, SEM and GGMs, the research endeavor outlined, as policy recommendations for financial institutions, the decisive importance of establishing an optimal board size, enhanced management skills, upward gender diversity (encompassed by women participation on board management), and structure (mainly a two-tier type, one management board and a distinctive supervisory board). These policies are fundamentals for the increased financial achievements and higher companies' performance.

The board size (BS) and company size (assets) were particularly grasped by GGMs as being strongly related (both directly and inversely) with the financial performance and profitability indicators. The endogenous behavior for the board size was accounted and its strong connection with the financial performance measures was attested, as well. The number and frequency of board meetings capture the commitment and involvement of directors in monitoring the companies' activities and are a way to ensure board diligence and effectiveness. Our own results enhance this proxy as being positively related to the presence of a CSR committee and having a positive impact on financial risk management (FRM). At the same time, the existence of a CSR sustainability committee and a corporate governance board committee, as well as its independence and a tight control of bribery, corruption, and fraud have been empirically evidenced by our results as positive credentials of an effective risk management strategy leading to an improved financial performance.

In this perspective, positive financial performance results will strengthen the confidence of creditors and investors in the activity and operation of the considered companies. These internal factors, less considered in terms of importance by some authors and sometimes neglected by companies, are however, extremely important and have a significant impact in shaping a company's financial performance (Liu et al. 2015).

Overall, the policy implications of our own findings relate to the recommendation for financial institutions to set and follow corporate governance rules and regulations, through the existence of an independent, highly-skilled, and active risk management committee, with proper responsibilities and functions, policies, and clear objectives aligned with those of the company.

The implications of our own findings for researchers and practitioners/companies relate to the managers' awareness of their ability to deal with the synergy between board characteristics and risk management disclosure, in order to enhance the firms' performance. This preview may help them achieve advanced and suitable policy orientations and decisions.

The research acknowledges as a main limitation the relatively reduced sample size. However, we configured the endeavor by reporting to two coordinates, namely Europe as a geographical coverage and focusing only on the financial services sector. At the same time, another limitation is related to the analysis performed only for 2019 considering the restricted access to relevant data covering a longer time span in the Thomson Reuters Eikon database.

Future research will overcome these limitations by analyzing the same credentials, through going back to previous years, in order to reveal certain dynamics and provide additional robustness. We will also target the relationship between board characteristics and environmental performance across various sectors of the economy, with spillovers on the financial performance and firm profitability, in a sustainable development setting and using a different methodological approach.

Author Contributions: Conceptualization, E.T., G.G.N., and M.C.; methodology, G.G.N.; software, G.G.N.; validation, E.T., G.G.N., and M.C.; formal analysis, G.G.N. and M.C.; investigation, G.G.N. and M.C.; resources, G.G.N. and I.M.G.; data curation, G.G.N., M.C., and I.M.G.; writing-original draft preparation, M.C., G.G.N., and I.M.G.; writing-review and editing, E.T., G.G.N., and M.C.; visualization, E.T.; supervision, E.T. All authors have contributed, read, and agreed to the published version of the manuscript.

Funding: This research received no external funding. 
Acknowledgments: The authors would like to thank the reviewers for their insightful comments and recommendations towards improving the manuscript.

Conflicts of Interest: The authors declare no conflict of interest.

\section{Appendix A}

Table A1. Detailed SEM results, maximum likelihood method (with missing values).

\begin{tabular}{|c|c|c|c|c|c|}
\hline \multirow{2}{*}{ Variables } & (1) & (2) & (3) & (4) & (5) \\
\hline & ROA & ROE & EBIT & EPS & DPS \\
\hline \multicolumn{6}{|l|}{ BCFC } \\
\hline FRM & $\begin{array}{l}1 \\
(.)\end{array}$ & $\begin{array}{c}1 \\
(.)\end{array}$ & $\begin{array}{l}1 \\
(.)\end{array}$ & $\begin{array}{l}1 \\
\text { (.) }\end{array}$ & 1 \\
\hline \multirow{2}{*}{ _cons } & $0.354^{* * *}$ & $0.354^{* * *}$ & $0.354^{* * *}$ & $0.354^{* * *}$ & $0.354^{* * * *}$ \\
\hline & $(0.0399)$ & $(0.0399)$ & $(0.0399)$ & $(0.0399)$ & $(0.0399)$ \\
\hline \multicolumn{6}{|l|}{ CGBC } \\
\hline FRM & $\begin{array}{c}0.518^{* * *} \\
(0.139)\end{array}$ & $\begin{array}{c}0.519 * * * \\
(0.138)\end{array}$ & $\begin{array}{c}0.549 * * * \\
(0.139)\end{array}$ & $\begin{array}{c}0.536^{* * *} \\
(0.139)\end{array}$ & $\begin{array}{c}0.536^{* * *} \\
(0.138)\end{array}$ \\
\hline \multirow{2}{*}{ _cons } & $0.278^{* * *}$ & $0.278^{* * *}$ & $0.278^{* * *}$ & $0.278^{* * *}$ & $0.278^{* * *}$ \\
\hline & $(0.0373)$ & $(0.0373)$ & $(0.0373)$ & $(0.0373)$ & $(0.0373)$ \\
\hline \multicolumn{6}{|l|}{ CCI } \\
\hline \multirow{2}{*}{ FRM } & -0.0621 & -0.0581 & -0.0652 & -0.0552 & -0.0526 \\
\hline & $(0.124)$ & $(0.124)$ & $(0.123)$ & $(0.125)$ & $(0.125)$ \\
\hline \multirow{2}{*}{ _cons } & $4.286^{* * *}$ & $4.286^{* * *}$ & $4.286^{* * *}$ & $4.286^{* * *}$ & $4.286^{* * *}$ \\
\hline & $(0.0343)$ & $(0.0343)$ & $(0.0343)$ & $(0.0343)$ & $(0.0343)$ \\
\hline \multicolumn{6}{|l|}{ BA } \\
\hline \multirow{2}{*}{ FRM } & -0.167 & -0.184 & -0.156 & -0.154 & -0.154 \\
\hline & $(0.152)$ & $(0.154)$ & $(0.151)$ & $(0.152)$ & $(0.152)$ \\
\hline \multirow{2}{*}{ _cons } & $0.424^{* * *}$ & $0.424^{* * *}$ & $0.424^{* * *}$ & $0.424^{* * *}$ & $0.424^{* * *}$ \\
\hline & $(0.0412)$ & $(0.0412)$ & $(0.0412)$ & $(0.0412)$ & $(0.0412)$ \\
\hline \multicolumn{6}{|l|}{$\mathrm{BM}$} \\
\hline \multirow{2}{*}{ FRM } & $4.389 *$ & 4.271 & 3.380 & 3.828 & 3.865 \\
\hline & $(2.229)$ & $(2.216)$ & (2.204) & (2.198) & $(2.186)$ \\
\hline \multirow{2}{*}{ _cons } & $11.87^{* * *}$ & $11.88^{* * *}$ & $11.87^{* * *}$ & $11.87^{* * *}$ & $11.87^{* * *}$ \\
\hline & $(0.604)$ & $(0.604)$ & $(0.605)$ & $(0.604)$ & $(0.604)$ \\
\hline \multicolumn{6}{|l|}{ BST } \\
\hline \multirow{2}{*}{ FRM } & 0.232 & 0.213 & 0.265 & 0.259 & 0.246 \\
\hline & $(0.209)$ & $(0.206)$ & $(0.202)$ & $(0.215)$ & $(0.211)$ \\
\hline \multirow{2}{*}{ _cons } & $1.583^{* * *}$ & $1.583^{* * *}$ & $1.583^{* * *}$ & $1.583^{* * *}$ & $1.583^{* * *}$ \\
\hline & $(0.0551)$ & $(0.0551)$ & $(0.0551)$ & $(0.0551)$ & $(0.0551)$ \\
\hline \multicolumn{6}{|l|}{ BS } \\
\hline \multirow{2}{*}{ FRM } & $8.633^{* * *}$ & $8.720^{* * *}$ & $8.450^{* * *}$ & $8.502 * * *$ & $8.479^{* * *}$ \\
\hline & $(1.440)$ & $(1.461)$ & $(1.429)$ & $(1.452)$ & (1.443) \\
\hline \multirow{2}{*}{ _cons } & $11.10^{* * *}$ & $11.10^{* * *}$ & $11.10^{* * *}$ & $11.10^{* * *}$ & $11.10^{* * *}$ \\
\hline & $(0.352)$ & $(0.352)$ & $(0.352)$ & $(0.352)$ & $(0.352)$ \\
\hline \multicolumn{6}{|l|}{ BBS } \\
\hline \multirow{2}{*}{ FRM } & -0.0878 & -0.111 & -0.0428 & -0.0653 & -0.0691 \\
\hline & $(0.112)$ & $(0.112)$ & $(0.108)$ & $(0.111)$ & $(0.110)$ \\
\hline & $0.854^{* * *}$ & $0.854^{* * *}$ & $0.854^{* * *}$ & $0.854^{* * *}$ & $0.854^{* * *}$ \\
\hline _cons & $(0.0294)$ & $(0.0294)$ & $(0.0294)$ & $(0.0294)$ & $(0.0294)$ \\
\hline MD & & & & & \\
\hline FRM & $0.329^{* * *}$ & $0.331^{* * *}$ & $0.315^{* * *}$ & $0.331^{* * *}$ & $0.330^{* * *}$ \\
\hline FRM & $(0.0891)$ & $(0.0888)$ & $(0.0893)$ & $(0.0893)$ & $(0.0888)$ \\
\hline & $0.0903^{* * *}$ & $0.0903^{* * *}$ & $0.0903^{* * *}$ & $0.0903^{* * *}$ & $0.0903^{* * *}$ \\
\hline _cons & $(0.0239)$ & $(0.0239)$ & $(0.0239)$ & $(0.0239)$ & $(0.0239)$ \\
\hline
\end{tabular}


Table A1. Cont.

\begin{tabular}{|c|c|c|c|c|c|}
\hline \multirow{2}{*}{ Variables } & (1) & (2) & (3) & (4) & (5) \\
\hline & ROA & ROE & EBIT & EPS & DPS \\
\hline \multicolumn{6}{|l|}{ WM } \\
\hline \multirow{2}{*}{ FRM } & 0.192 & 0.189 & 0.226 & 0.211 & 0.210 \\
\hline & $(0.178)$ & (0.179) & (0.173) & $(0.177)$ & $(0.176)$ \\
\hline \multirow{2}{*}{ _cons } & $3.469 * * *$ & $3.469^{* * *}$ & $3.467^{* * *}$ & $3.468 * * *$ & $3.468^{* * *}$ \\
\hline & $(0.0476)$ & $(0.0475)$ & $(0.0474)$ & $(0.0475)$ & $(0.0475)$ \\
\hline \multicolumn{6}{|l|}{ ASSETS } \\
\hline \multirow{2}{*}{ FRM } & $5.360^{* * *}$ & $4.962 * * *$ & $5.754^{* * *}$ & $5.429^{* * *}$ & $5.298^{* * *}$ \\
\hline & $(0.840)$ & $(0.785)$ & $(0.728)$ & $(1.102)$ & $(0.993)$ \\
\hline \multirow{2}{*}{ _cons } & $24.86^{* * *}$ & $24.87^{* * *}$ & $24.85^{* * *}$ & $24.86^{* * *}$ & $24.86^{* * *}$ \\
\hline & $(0.148)$ & $(0.148)$ & $(0.148)$ & $(0.149)$ & $(0.149)$ \\
\hline \multicolumn{6}{|l|}{ BGD } \\
\hline \multirow{2}{*}{ FRM } & 0.164 & 0.113 & 0.206 & 0.175 & 0.162 \\
\hline & $(0.158)$ & $(0.159)$ & $(0.150)$ & (0.173) & $(0.167)$ \\
\hline \multirow{2}{*}{ _cons } & $3.313^{* * *}$ & $3.313^{* * *}$ & $3.313^{* * *}$ & $3.313 * * *$ & $3.313^{* * *}$ \\
\hline & $(0.0408)$ & $(0.0408)$ & $(0.0408)$ & $(0.0408)$ & $(0.0408)$ \\
\hline \multicolumn{6}{|l|}{ / } \\
\hline \multirow{2}{*}{$\operatorname{var}(\mathrm{e} . \mathrm{BCFC})$} & $0.141^{* * *}$ & $0.136^{* * *}$ & $0.146^{* * *}$ & $0.142^{* * *}$ & $0.140^{* * *}$ \\
\hline & $(0.0195)$ & $(0.0194)$ & $(0.0181)$ & $(0.0223)$ & $(0.0213)$ \\
\hline \multirow{2}{*}{ var(e.CGBC) } & $0.177^{* * *}$ & $0.176^{* * *}$ & $0.176^{* * *}$ & $0.176^{* * *}$ & $0.175^{* * *}$ \\
\hline & $(0.0213)$ & $(0.0214)$ & $(0.0210)$ & $(0.0215)$ & $(0.0214)$ \\
\hline \multirow{2}{*}{$\operatorname{var}(\mathrm{e} . \mathrm{CCI})$} & $0.142^{* * *}$ & $0.142^{* * *}$ & $0.142^{* * *}$ & $0.142 * * *$ & $0.142^{* * *}$ \\
\hline & $(0.0182)$ & $(0.0182)$ & $(0.0182)$ & $(0.0182)$ & $(0.0182)$ \\
\hline \multirow{2}{*}{$\operatorname{var}(\mathrm{e} . \mathrm{BA})$} & $0.242 * * *$ & $0.241^{* * *}$ & $0.242^{* * *}$ & $0.242^{* * *}$ & $0.242^{* * *}$ \\
\hline & $(0.0285)$ & $(0.0285)$ & $(0.0286)$ & $(0.0286)$ & $(0.0286)$ \\
\hline \multirow{2}{*}{$\operatorname{var}(\mathrm{e} . \mathrm{BM})$} & $43.02 * * *$ & $43.04^{* * *}$ & $43.77^{* * *}$ & $43.44^{* * *}$ & $43.38^{* * *}$ \\
\hline & $(5.558)$ & $(5.563)$ & $(5.617)$ & $(5.592)$ & $(5.587)$ \\
\hline \multirow{2}{*}{$\operatorname{var}(\mathrm{e} . \mathrm{BST})$} & $0.433^{* * *}$ & $0.433^{* * *}$ & $0.432 * * *$ & $0.432^{* * *}$ & $0.432^{* * *}$ \\
\hline & $(0.0511)$ & $(0.0512)$ & $(0.0509)$ & $(0.0510)$ & $(0.0511)$ \\
\hline \multirow{2}{*}{ var(e.BS) } & $11.27^{* * *}$ & $10.77^{* * *}$ & $11.88^{* * *}$ & $11.51 * * *$ & $11.40^{* * *}$ \\
\hline & $(1.555)$ & $(1.584)$ & (1.483) & (1.619) & $(1.585)$ \\
\hline \multirow{2}{*}{$\operatorname{var}(\mathrm{e} . \mathrm{BBS})$} & $0.124^{* * *}$ & $0.123^{* * *}$ & $0.124^{* * *}$ & $0.124^{* * *}$ & $0.124^{* * *}$ \\
\hline & $(0.0146)$ & $(0.0146)$ & $(0.0147)$ & $(0.0146)$ & $(0.0146)$ \\
\hline \multirow{2}{*}{$\operatorname{var}(\mathrm{e} . \mathrm{MD})$} & $0.0726^{* * *}$ & $0.0720 * * *$ & $0.0739^{* * *}$ & $0.0726^{* * *}$ & $0.0724^{* * *}$ \\
\hline & $(0.00875)$ & $(0.00876)$ & $(0.00878)$ & $(0.00880)$ & $(0.00878)$ \\
\hline \multirow{2}{*}{$\operatorname{var}(\mathrm{e} . \mathrm{WM})$} & $0.207^{* * *}$ & $0.207^{* * *}$ & $0.206^{* * *}$ & $0.206^{* * *}$ & $0.206^{* * *}$ \\
\hline & $(0.0298)$ & (0.0298) & $(0.0296)$ & $(0.0297)$ & $(0.0297)$ \\
\hline $\operatorname{var}(\mathrm{A} A$ SSETS $)$ & 0.404 & 0.618 * & 0.181 & 0.355 & 0.416 \\
\hline var(e.ASSEIS) & $(0.275)$ & $(0.285)$ & $(0.122)$ & $(0.412)$ & $(0.363)$ \\
\hline & $0.438 * * *$ & & & & \\
\hline $\operatorname{var}(\mathrm{e} . \mathrm{ROA})$ & $(0.0618)$ & & & & \\
\hline $\operatorname{var}($ e BGD) & $0.229 * * *$ & $0.231^{* * *}$ & $0.228^{* * *}$ & $0.229 * * *$ & $0.229^{* * *}$ \\
\hline $\operatorname{var}(\mathrm{e} . \mathrm{BGD})$ & $(0.0276)$ & $(0.0277)$ & $(0.0274)$ & $(0.0276)$ & $(0.0276)$ \\
\hline & $0.0878^{* * *}$ & $0.0927^{* * *}$ & $0.0832^{* * *}$ & $0.0872^{* * *}$ & $0.0892^{* * *}$ \\
\hline var(FRM) & $(0.0235)$ & $(0.0243)$ & $(0.0216)$ & $(0.0258)$ & $(0.0253)$ \\
\hline var(e.ROE) & & $0.494^{* * *}$ & & & \\
\hline & & $(0.0647)$ & & & \\
\hline var(e.EBIT) & & & $\begin{array}{c}0.444^{* * *} \\
(0.103)\end{array}$ & & \\
\hline var(e.EPS) & & & & $\begin{array}{c}2.513^{* * *} \\
(0.317)\end{array}$ & \\
\hline var(e.DPS) & & & & & $\begin{array}{c}2.123^{* * *} \\
(0.282)\end{array}$ \\
\hline
\end{tabular}


Table A1. Cont.

\begin{tabular}{|c|c|c|c|c|c|}
\hline \multirow{2}{*}{ Variables } & (1) & (2) & (3) & (4) & (5) \\
\hline & ROA & ROE & EBIT & EPS & DPS \\
\hline \multicolumn{6}{|l|}{ ROA } \\
\hline FRM & $\begin{array}{c}-1.414^{* * *} \\
(0.297)\end{array}$ & & & & \\
\hline _cons & $\begin{array}{c}-0.225^{* *} \\
(0.0722)\end{array}$ & & & & \\
\hline \multicolumn{6}{|l|}{ ROE } \\
\hline FRM & & $\begin{array}{c}-0.931 \text { *** } \\
(0.264)\end{array}$ & & & \\
\hline _cons & & $\begin{array}{l}2.164^{* * *} \\
(0.0670)\end{array}$ & & & \\
\hline \multicolumn{6}{|l|}{ EBIT } \\
\hline FRM & & & $\begin{array}{c}4.897^{* * *} \\
(0.616)\end{array}$ & & \\
\hline _cons & & & $\begin{array}{c}20.47^{* * *} \\
(0.136)\end{array}$ & & \\
\hline \multicolumn{6}{|l|}{ EPS } \\
\hline FRM & & & & $\begin{array}{c}0.297 \\
(0.607)\end{array}$ & \\
\hline _cons & & & & $\begin{array}{c}-0.00555 \\
(0.142)\end{array}$ & \\
\hline \multicolumn{6}{|l|}{ DPS } \\
\hline FRM & & & & & $\begin{array}{c}0.168 \\
(0.521)\end{array}$ \\
\hline _cons & & & & & $\begin{array}{c}-0.471 \text { *** } \\
(0.138)\end{array}$ \\
\hline$N$ & 144 & 144 & 144 & 144 & 144 \\
\hline
\end{tabular}

Note: Standard errors in parentheses, ${ }^{*} p<0.05,{ }^{* *} p<0.01,{ }^{* * *} p<0.001$. Source: Authors ${ }^{\prime}$ research in Stata 16.

Table A2. Cronbach's alpha for the five SEM models.

\begin{tabular}{cccccc}
\hline Items & SEM-1 & SEM-2 & SEM-3 & SEM-4 & SEM-5 \\
\hline BCFC & 0.4440 & 0.4548 & 0.5258 & 0.4719 & 0.4480 \\
CGBC & 0.5288 & 0.5343 & 0.5112 & 0.4223 & 0.4718 \\
CCI & 0.5475 & 0.6458 & 0.6360 & 0.5088 & 0.6952 \\
BA & 0.5425 & 0.5398 & 0.6433 & 0.6213 & 0.4378 \\
BM & 0.5157 & 0.5194 & 0.5543 & 0.4384 & 0.4072 \\
BST & 0.5692 & 0.6730 & 0.5064 & 0.4621 & 0.6547 \\
BS & 0.4203 & 0.5210 & 0.450 & 0.4747 & 0.4017 \\
BBS & 0.5324 & 0.5316 & 0.5499 & 0.5867 & 0.6801 \\
MD & 0.5150 & 0.5149 & 0.5806 & 0.4256 & 0.4598 \\
WM & 0.5431 & 0.5454 & 0.5004 & 0.6704 & 0.4295 \\
ASSETS & 0.6608 & 0.6724 & 0.5658 & 0.4085 & 0.4385 \\
BGD & 0.5485 & 0.6477 & 0.5540 & 0.6956 & 0.6668 \\
ROA & 0.6830 & & & & \\
ROE & & 0.6830 & & & \\
EBIT & & & 0.5772 & 0.4271 & \\
EPS & & 0.6370 & 0.6150 & 0.6705 & 0.6411 \\
DPS & & & &
\end{tabular}

Source: Authors' contribution in Stata 16. 
Table A3. Wald tests for equations associated with the SEM models.

\begin{tabular}{|c|c|c|c|c|c|c|c|c|c|c|}
\hline \multirow{2}{*}{ Variables } & \multicolumn{2}{|c|}{ SEM-1 } & \multicolumn{2}{|c|}{ SEM-2 } & \multicolumn{2}{|c|}{ SEM-3 } & \multicolumn{2}{|c|}{ SEM-4 } & \multicolumn{2}{|c|}{ SEM-5 } \\
\hline & $\mathrm{Chi}^{2}$ & $p$ & $\mathrm{Chi}^{2}$ & $p$ & $\mathrm{Chi}^{2}$ & $p$ & $\mathrm{Chi}^{2}$ & $p$ & $\mathrm{Chi}^{2}$ & $p$ \\
\hline BCFC & 0 & - & 0 & - & 0 & - & 0 & - & 0 & _- \\
\hline CGBC & 14.00 & 0.000 & 14.15 & 0.000 & 15.50 & 0.000 & 14.87 & 0.000 & 15.08 & 0.000 \\
\hline CCI & 1.25 & 0.115 & 1.22 & 0.338 & 1.28 & 0.296 & 1.19 & 0.259 & 1.18 & 0.272 \\
\hline BA & 1.19 & 0.274 & 1.44 & 0.230 & 1.07 & 0.302 & 1.02 & 0.311 & 1.03 & 0.310 \\
\hline $\mathrm{BM}$ & 3.88 & 0.049 & 3.72 & 0.053 & 2.35 & 0.125 & 3.03 & 0.081 & 3.12 & 0.077 \\
\hline BST & 1.23 & 0.267 & 1.06 & 0.302 & 1.72 & 0.189 & 1.46 & 0.227 & 1.36 & 0.243 \\
\hline BS & 35.92 & 0.000 & 35.61 & 0.000 & 34.96 & 0.000 & 34.27 & 0.000 & 34.54 & 0.000 \\
\hline BBS & 1.62 & 0.032 & 0.98 & 0.321 & 1.16 & 0.292 & 1.35 & 0.256 & 1.39 & 0.231 \\
\hline MD & 13.64 & 0.000 & 13.93 & 0.000 & 12.46 & 0.000 & 13.75 & 0.000 & 13.82 & 0.000 \\
\hline WM & 1.15 & 0.283 & 1.12 & 0.290 & 1.71 & 0.191 & 1.42 & 0.233 & 1.42 & 0.233 \\
\hline ASSETS & 40.72 & 0.000 & 39.99 & 0.000 & 62.46 & 0.000 & 24.26 & 0.000 & 28.45 & 0.000 \\
\hline BGD & 1.08 & 0.299 & 1.50 & 0.2774 & 1.89 & 0.168 & 1.03 & 0.310 & 1.94 & 0.212 \\
\hline ROA & 22.69 & 0.000 & & & & & & & & \\
\hline ROE & & & 12.42 & 0.000 & & & & & & \\
\hline EBIT & & & & & 63.13 & 0.000 & & & & \\
\hline EPS & & & & & & & 3.24 & 0.024 & & \\
\hline DPS & & & & & & & & & 3.10 & 0.097 \\
\hline
\end{tabular}

Source: Authors' contribution in Stata 16.

Table A4. Goodness-of-fit tests associated with the SEM models.

\begin{tabular}{|c|c|c|c|c|c|}
\hline Explanations & SEM-1 & SEM-2 & SEM-3 & SEM-4 & SEM-5 \\
\hline \multicolumn{6}{|c|}{ "Likelihood ratio" } \\
\hline “Model vs. saturated chi ${ }^{2} \_$ms (15)" & 163.732 & 170.003 & 153.322 & 181.727 & 167.931 \\
\hline$p>$ chi $^{2}$ & 0.000 & 0.000 & 0.000 & 0.000 & 0.000 \\
\hline “Baseline vs. saturated $\mathrm{chi}^{2}{ }^{2}$ bs $(24)$ ” & 326.941 & 318.609 & 455.538 & 316.227 & 302.292 \\
\hline$p>\operatorname{chi}^{2}$ & 0.000 & 0.000 & 0.000 & 0.000 & 0.000 \\
\hline \multicolumn{6}{|c|}{ "Information criteria" } \\
\hline “AIC (Akaike's information criterion)" & 3750.401 & 3788.584 & 3789.857 & 3985.453 & 3917.438 \\
\hline "BIC (Bayesian information criterion)" & 3866.224 & 3904.407 & 3905.680 & 4101.276 & 4033.261 \\
\hline \multicolumn{6}{|c|}{ "Baseline comparison" } \\
\hline "CFI (Comparative fit index)" & 0.603 & 0.564 & 0.766 & 0.510 & 0.541 \\
\hline “TLI (Tucker-Lewis index)” & 0.524 & 0.476 & 0.719 & 0.412 & 0.449 \\
\hline \multicolumn{6}{|c|}{ "Size of residuals" } \\
\hline “CD (Coefficient of determination)” & 0.891 & 0.848 & 0.955 & 0.898 & 0.883 \\
\hline
\end{tabular}

\section{References}

Abdullah, Shamsul Nahar. 2004. Board composition, CEO duality and performance among Malaysian listed companies. Corporate Governance 4: 47-61. [CrossRef]

Abdullah, Maizatulakma, Zaleha Abdul Shukor, Zakiah Muhammadun Mohamed, and Azlina Ahmad. 2015. Risk management disclosure: A study on the effect of voluntary risk management disclosure toward firm value. Journal of Applied Accounting Research 16: 400-32. [CrossRef]

Al-Matari, Ebrahim Mohammmed, Abdullah Kaid Al-Swidi, Faudziah Hanim Bt Fadzil, and Yahya Ali Al-Matari. 2012. The impact of board characteristics on firm performance: Evidence from nonfinancial listed companies in Kuwaiti Stock Exchange. International Journal of Accounting and Financial Reporting 2: 310-32. [CrossRef]

Anton, Sorin Gabriel, and Anca Elena Afloarei Nucu. 2020. Enterprise Risk Management: A Literature Review and Agenda for Future Research. Journal of Risk and Financial Management 13: 281. [CrossRef]

Băndoi, Anca, Claudiu George Bocean, Mara Del Baldo, Lucian Mandache, Leonardo Geo Mănescu, and Cătălina Soriana Sitnikov. 2021. Including Sustainable Reporting Practices in Corporate Management Reports: Assessing the Impact of Transparency on Economic Performance. Sustainability 13: 940. [CrossRef]

Beran, Tanya, and Claudio Violato. 2010. Structural equation modeling in medical research. BMC Research Notes 3: 267. [CrossRef] Berrone, Pascual, and Luis Gomez-Mejia. 2009. Environmental Performance and Executive Compensation: An Integrated AgencyInstitutional Perspective. Academy of Management Journal 52: 103-26. [CrossRef]

Bonn, Ingrid. 2004. Board Structure and Firm Performance: Evidence from Australia. Journal of Management E Organization 10: 14-24. 
Brannick, T. Michael. 1995. Critical comments on applying covariance structure modeling. Journal of Organizational Behavior 16: 201-13. [CrossRef]

Brannick, T. Michael. 2020. Structural Equation Modeling (SEM). Available online: http:/ / faculty.cas.usf.edu/mbrannick/regression/ SEM.html (accessed on 12 January 2021).

Bunea, Mariana, and Vasile Dinu. 2020. The relationship between the boards characteristics and the risk management of the Romanian banking sector. Journal of Business Economics and Management 21: 1248-68. [CrossRef]

Cho, Sang Jun, Chune Young Chung, and Jason Young. 2019. Study on the Relationship between CSR and Financial Performance. Sustainability 11: 343. [CrossRef]

Coffey, Betty, and Jia Wang. 1998. Board Diversity and Managerial Control as Predictors of Corporate Social Performance. Journal of Business Ethics 17: 1595-1603. [CrossRef]

Coles, Jerilyn, Victoria McWilliams, and Nilanjan Sen. 2001. An examination of the relationship of governance mechanisms to performance. Journal of Management 27: 23-50. [CrossRef]

De Villiers, Charl, Vic Naiker, and Chris J. van Staden. 2011. The Effect of Board Characteristics on Firm Environmental Performance. Journal of Management 37: 1636-63. [CrossRef]

Dehaene, Alexander, Veerle De Vuyst, and Hubert Ooghe. 2001. Corporate Performance and Board Structure in Belgian Companies. Long Range Planning 34: 383-98. [CrossRef]

Du Rietz, Anita, and Magnus Henrekson. 2000. Testing the Female Underperformance Hypothesis. Small Business Economics 14: 1-10. [CrossRef]

Eckles, David L., Robert E. Hoyt, and Steve M. Miller. 2014. The impact of enterprise risk management on the marginal cost of reducing risk: Evidence from the insurance industry. Journal of Banking E Finance 49: 409-23.

Epskamp, Sacha, Lourens J. Waldorp, René Mõttus, and Denny Borsboom. 2018. The Gaussian Graphical Model in Cross-Sectional and Time-Series Data. Multivariate Behavioral Research 53: 453-80. [CrossRef]

Florio, Cristina, and Giulia Leoni. 2017. Enterprise risk management and firm performance: The Italian case. British Accounting Review 49: 56-74. [CrossRef]

Gujarati, Damodar. 2003. Basic econometrics, 4th ed. Boston: McGraw Hill.

Haque, Faizul. 2017. The effects of board characteristics and sustainable compensation policy on carbon performance of UK firms. The British Accounting Review 49: 347-64. [CrossRef]

Hosny, Amr. 2017. Political stability, firm characteristics and performance: Evidence from 6,083 private firms in the Middle East. Review of Middle East Economics and Finance 13: 1-21. [CrossRef]

Huse, Morten, and Anne Grethe Solberg. 2006. Gender-related boardroom dynamics: How Scandinavian women make and can make contributions on corporate boards. Women in Management Review 21: 113-30. [CrossRef]

Jia, Ming, and Zhe Zhang. 2013. Critical Mass of Women on BODs, Multiple Identities, and Corporate Philanthropic Disaster Response: Evidence from Privately Owned Chinese Firms. Journal of Business Ethics 118: 303-17. [CrossRef]

Kakanda, Mohammed Mahmud, and Basariah Salim. 2017. Corporate governance, risk management disclosure, and firm performance: A theoretical and empirical review perspective. Asian Economic and Financial Review 7: 836-45. [CrossRef]

Kiel, C. Geoffrey, and Gavin J. Nicholson. 2003. Board Composition and Corporate Performance: How the Australian experience informs contrasting theories of corporate governance. Corporate Governance: An International Review 11: 189-205. [CrossRef]

Lechner, Philipp, and Nadine Gatzert. 2018. Determinants and value of enterprise risk management: Empirical evidence from Germany. European Journal of Finance 24: 867-87. [CrossRef]

Liao, Lin, Le Luo, and Qingliang Tang. 2015. Gender diversity, board independence, environmental committee and greenhouse gas disclosure. The British Accounting Review 47: 409-24. [CrossRef]

Liu, Yu, Mihail K. Miletknov, Zuobao Wei, and Tina Yang. 2015. Board Independence and Firm Performance in China. Journal of Corporate Finance 30: 223-44. [CrossRef]

Millet-Reyes, Benedicte, and Ronald Zhao. 2010. A Comparison Between One-Tier and Two-Tier Board Structures in France. Journal of International Financial Management \& Accounting 21: 279-310.

Murphy, Steven, and Michael McIntyre. 2007. Board of director performance: A group dynamics perspective. Corporate Governance. 7: 209-24. [CrossRef]

Muturi, Willy, and Maleya M. Omondi. 2013. Factors Affecting the Financial Performance of Listed Companies at the Nairobi Securities Exchange in Kenya. Research Journal of Finance and Accounting 4: 99-105.

Noja, Gratiela Georgiana, Mirela Cristea, Cecilia Nicoleta Jurcut, Alexandru Buglea, and Ioan Lala Popa. 2020. Management financial incentives and firm performance in a sustainable development framework: Empirical evidence from European companies. Sustainability 12: 7247. [CrossRef]

Nunkoo, Robin, and Haywantee Ramkissoon. 2012. Structural equation modelling and regression analysis in tourism research. Current Issues in Tourism 15: 777-802. [CrossRef]

Abu, Odudu Seini, Arumona James Okpeh, and Uchenna James Okpe. 2016. Board Characteristics and Financial Performance of Deposit Money Banks in Nigeria. International Journal of Business and Social Science 7: 159-73.

Ozen, Ercan, Eser Yesildag, and Mustafa Soba. 2015. TOPSIS performance evaluation measures and relation between financial ratios and stock returns. Journal of Economics Finance and Accounting 2: 482-500. [CrossRef] 
Pirtea, Marilen, Cristina Nicolescu, and Claudiu Botoc. 2014. Do Romanian Companies Follow Pecking Order Financing? Economic Computation and Economic Cybernetics Studies and Research 48: 1-15.

Pucheta-Martínez, Maria Consuelo, and Isabel Gallego-Álvarez. 2020. Do board characteristics drive firm performance? An international perspective. Review of Managerial Science 14: 1251-97. [CrossRef]

Randöy, Trond, Steen Thomsen, and Lars Oxelheim. 2006. A Nordic Perspective on Corporate Board Diversity. Copenhagen: Nordic Council of Ministers, Nordic Innovation Centre, pp. 2-28.

Refinitiv. 2020. Thomson Reuters Eikon Database. New Yrok: Refinitiv.

Rose, Caspar. 2005. The composition of semi-two-tier corporate boards and firm performance. Corporate Governance: An International Review 13: 691-701. [CrossRef]

Sichigea, Mirela, Marian Ilie Siminica, Daniel Circiumaru, Silviu Carstina, and Nela Loredana Caraba-Meita. 2020. A comparative approach of the environmental performance between periods with positive and negative accounting returns of EEA companies. Sustainability 12: 7382. [CrossRef]

Skandalis, Konstantinos, Panagiotis Liargovas, and Anna A. Merika. 2008. Firm management competence: Does it Matter? International Journal of Business and Economics 7: 167-80.

Solomon, Jill Frances, Aris Solomon, Simon D. Norton, and Nathan L. Joseph. 2000. A conceptual framework for corporate risk disclosure emerging from the agenda for corporate governance reform. British Accounting Review 32: 447-78. [CrossRef]

Suciu, Marta-Christina, Gratiela Georgiana Noja, and Mirela Cristea. 2020. Diversity, social inclusion and human capital development as fundamentals of financial performance and risk mitigation. Amfiteatru Economic 22: 742-57.

Swartz, N. P., and Steven Firer. 2005. Board structure and intellectual capital performance in South Africa. Meditari Accountancy Research 13: 145-66. [CrossRef]

Ujunwa, Augustine. 2012. Board characteristics and the financial performance of Nigerian quoted firms. Corporate Governance 12: 656-74. [CrossRef]

Yermack, David. 1996. Higher market valuation of companies with a small board of directors, Journal of Financial Economics 40: 185-211. Journal of Financial Economics 40: 185-211. [CrossRef] 